\title{
STUDI KOMPARASI HASIL BELAJAR KIMIA PADA MATERI KOLOID MENGGUNAKAN MODEL PEMBELAJARAN BERBASIS PROYEK DAN MODEL PEMBELAJARAN BERBASIS MASALAH SISWA KELAS XI IPA MAN 2 MATARAM TAHUN AJARAN 2013/2014
}

\author{
Eka Hesti Safitri ${ }^{1}$, Jeckson Siahaan ${ }^{2}$, Syarifa Wahidah Al Idrus ${ }^{2}$ \\ 1 Alumni Program Studi Pendidikan Kimia FKIP, Universitas Mataram \\ 2 Program Studi Studi Pendidikan Kimia, FKIP, Universitas Mataram \\ Jln. Majapahit No. 62 Telp.(0370) 623873 Pes.122 Fax. 634918 Mataram 83125 \\ Email: idahsya76@gmail.com
}

\begin{abstract}
Abstrak: Penelitian ini merupakan penelitian quasi experimental (eksperimen semu) menggunakan Post-test Only Nonequivalent Control Group Design yang bertujuan untuk mengetahui ada atau tidaknya perbedaan hasil belajar kimia siswa menggunakan model pembelajaran berbasis proyek dan model pembelajaran berbasis masalah di kelas XI IPA MAN 2 Mataram Tahun Ajaran 2013/2014.Sampel penelitian diambil dengan teknik Purposive Sampling dan terpilih dua kelas sebagai kelas eksperimen, yaitu kelas XI IPA U1 (kelas ekperimen 1) dan kelas XI IPA U2 (kelas ekperimen 2).Data hasil belajar kognitif diperoleh melalui tes tertulis (post test) yang dianalisis menggunakan uji beda (uji t). Hasil penelitian menunjukkan bahwa pada kelas eksperimen I diperoleh nilai rata-rata 67 dengan ketuntasan klasikal 7,69\% sedangkan pada kelas eksperimen II diperoleh nilai rata-rata 70 dengan ketuntasan klasikal 28,57\%. Hasil uji-t dua pihak pada taraf signifikan $5 \%$ diperoleh $\mathrm{t}_{\text {hitung }}=-0,4709$ dan $\mathrm{t}_{\text {tabel }}=2,060$, sehingga $\mathrm{t}_{\text {hitung }}$ berada pada daerah penerimaan adalah Ho diantara -2,060 dan +2,060 yang berarti Ho pada penelitian ini diterima. Hal ini menunjukkan bahwa tidak terdapat perbedaan yang signifikan hasil belajar kimia antara siswa yang diterapkan model pembelajaran berbasis proyek dan model pembelajaran berbasis masalah siswa kelas XI IPA MAN 2 Mataram Tahun Ajaran $2013 / 2014$.
\end{abstract}

Kata kunci: Koloid, Model pembelajaran berbasis proyek,Model pembelajaran berbasis masalah

\begin{abstract}
The aims of this quasi experimental research is to compare the chemistry study result by using the project based learning model and problem based learning model at class XI science of MAN 2 Mataram in academic year 2013/2014. Sample of this research were class XI science U1 as experiment I class and class XI science U2 as experiment II class which taken by using purposive sampling technique.Data cognitive of the result study obtained through a written test (post-test) were analyzed using a different test ( $t$ test). The results showed that the experimental class I obtained an average value of 67 with classical completeness of $7.69 \%$ while the experimental class II obtained an average value of 70 with classical completeness $28.57 \%$. T-test results of the unequal sample at the significant level of 5\% was obtained $t_{\text {calculation }}=-0,4709$ and $t_{\text {table }}=2,060$, with the result that $t_{\text {calculation }}$ in the range from to $-2,060$ and $+2,060$ which means that the Ho in this research is approved. In conclusion, there is no significant difference in result study between students who are taught chemistry using project-based learning model and the problem based learning model students of class XI IPA 2 Mataram MAN in Academic Year 2013/2014.
\end{abstract}

Key words: Colloid, project based learning model, the problem based learning model.

\section{PENDAHULUAN}

Salah satu permasalahan pembelajaran kimia saat ini adalah kesulitan sebagian besar guru kimia dalam menerapkan model pembelajaran yang efektif dalam menyampaikan materi kimia. Selama ini, kegiatan pembelajaran masih dilakukan dengan mengharuskan siswa untuk menghafal konsep kimia. Padahal konsep tersebut bisa dikaitkan dengan kehidupan sehari-hari siswa dengan menerapkan model pembelajaran yang efektif sesuai dengan materi ajar.Namun, sebagian besar guru kimia masih sulit berkreativitas dalam menggunakan model pembelajaran yang relevan dengan materi ajar.

Menurut Manasikana [1], salah satu faktor eksternal yang menentukan keberhasilan proses pembelajaran yaitu model/metode pembelajaran. Metode pembelajaran yang sering digunakan di kelas XI IPA tahun ajaran 2013/2014 MAN 2 Mataram pada mata pelajaran kimia adalah ceramah, diskusi kelas, dan tugas. Berdasarkan hasil wawancara, metode diskusi yang digunakan adalah diskusi secara klasikal yaitu guru bersama-sama siswa membahas tugas/soal latihan.Metode pembelajaran seperti ini termasuk ke dalam metode pembelajaran konvensional yang berpusat pada guru (teacher center).Metode pembelajaran ini digunakan oleh guru kimia di MAN 2 Mataram karena dianggap memiliki kelebihan, salah satunya dapat mencegah terjadinya miskonsepsi pada siswa.Namun, hasil belajar kimia siswa yang belum dapat mencapai nilai KKM menunjukkan bahwa harus ada yang diperbaiki dalam pembelajaran kimia, khususnya metode atau model pembelajaran yang diterapkan.

Berdasarkan prinsip yang dikembangkan dalam kurikulum KTSP, yaitu bahwa peserta didik berada pada posisi sentral dan aktif dalam belajar.Maka, siswa diberikan otonomi untuk mengkonstruk dan mengembangkan pengetahuannya [2]. Sesuai kurikulum KTSP, perlu bertolak dari sistem yang lama yaitu pembelajaran berpusat pada guru (teacher center learning) menuju pembelajaran yang berpusat pada siswa (student center learning). 
Model pembelajaran yang berpusat pada siswa telah banyak diteliti dan dikembangkan, di antaranya adalah model pembelajaran berbasis proyek (project based learning) dan model pembelajaran berbasis masalah (problem based learning). Model pembelajaran berbasis proyek merupakan metode pembelajaran yang mengacu pada filosofis konstruktivisme, yaitu pengetahuan merupakan hasil konstruksi kognitif melalui suatu aktivitas siswa yang meliputi keterampilan maupun sikap ilmiah siswa sehingga siswa dapat mengkonstruksi pengetahuannya sendiri dan bermakna melalui pengalaman yang nyata [3].

Adapun model pembelajaran berbasis masalah merupakan strategi pengajaran yang inovatif dimana guru mendorong siswa untuk mengembangkan kemampuan dalam pemecahan masalah, kreativitas dan keterampilan berpikir kritis [4]. Ayşe [5] menjelaskan bahwa proses pembelajaran berbasis masalah terutama didasarkan pada pemecahan masalah termasuk mentransfer pengetahuan dan proses menghasilkan solusi nyata.

Penelitian sebelumnya yang dilakukan oleh Noordin [4] yang membandingkan antara model pembelajaran berbasis proyek dan model pembelajaran berbasis masalah di pendidikan teknik, memberikan hasil bahwa pembelajaran berbasis proyek lebih cocok untuk pendidikan teknik. Hal ini disebabkan karena pendekatan pembelajaran berbasis masalah berfokus pada penelitian dan penyelidikan untuk memecahkan masalah, sedangkan pendekatan pembelajaran berbasis proyekberfokus pada produk akhir dan seluruh proses produksi. Pembelajaran berbasis masalah dimulai dengan masalah yang menjadi fokus utama dari setiap kemajuan dalam pembelajaran.Rencana dan kerja kelompok yang dilakukan oleh siswa diarahkan untuk memecahkan masalah. Di sisi lain, pembelajaran berbasis proyek dimulai dengan tugas kelompok untuk melaksanakan satu atau lebih tugas yang mengarah pada produksi produk akhir.

Dari uraian di atas, dapat diketahui bahwa kedua metode tersebut memiliki kemiripan yaitu siswa sama-sama mengerjakan tugas dalam kelompok dimana setiap kelompok berusaha memecahkan beberapa permasalahan atau soal yang diberikan oleh guru. Namun, ada perbedaan yang paling terlihat yaitu pada model pembelajaran berbasis proyeksiswa dilatih mecari sendiri permasalahan di lingkungan sekitar yang akan diselesaikan dalam tugas proyek sebagai solusi dari permasalahan tersebut. Sementara pada model pembelajaran berbasis masalah, permasalahan yang diajukan oleh guru harus dijawab siswa melalui penelitian untuk memecahkan masalah.

Kedua model pembelajaran di atas tentunya memiliki kelebihan dan kekurangan.Peneliti inginmengetahui model pembelajaran mana yang lebih baik dan mampu meningkatkan hasil belajar siswa khususnya pada materi koloid. Hipotesis dari penelitian ini adalah tidak terdapat perbedaan hasil belajar kimia yang signifikan antara siswa yang diajar menggunakan Model Pembelajaran Berbasis Proyek dengan Model
Pembelajaran Berbasis Masalah pada siswa kelas XI IPA Semester 2 MAN2Mataram Tahun Ajaran 2013/2014".

\section{METODE PENELITIAN}

Penelitian ini dimulai dengan tahap persiapan penelitian dari bulan Maret 2014 dan pelaksanaan penelitian yang berakhir pada bulan Mei 2014 di MAN 2 Mataram. Jenis penelitian ini adalah Quasi Eksperiment menggunakan Post-test Only Nonequivalent Control Group Design.Variabel bebas dalam penelitian ini adalah model pembelajaran berbasis proyek dan model pembelajaran berbasis masalah.Variabel terikathasil belajar siswa Kelas XI IPA MAN 2 Mataram. Populasi dalam penelitian ini adalah seluruh kelas XI IPA MAN 2 Mataram.Sampel penelitian diambil dengan teknik Purposive Sampling dan terpilih dua kelas sebagai kelas eksperimen, yaitu kelas XI U1 (kelas ekperimen 1) dan kelas XI U2 (kelas ekperimen 2).Teknik pengambilan data menggunakan lembar observasi dan dokumentasi. Hasil belajar siswa diukur satu kali menggunakan post test. Selanjutnya, hipotesis penelitian dibuktikan melalui hasil uji-t dari post test yang sebelumnya sudah diuji prasyarat menggunakan uji normalitas dan homogenitas. Uji normalitas data dapat dihitung dengan menggunakan rumus Chi kuadrat [6]. Untuk melihat pengaruh perlakuan atau untuk membuktikan hipotesis yang diajukan, maka data tersebut diolah dengan menggunakan rumus uji-t (uji beda) sampel ganda dengan taraf signifikan 5\% [7].

Hipotesis penelitian ini adalah tidak terdapat perbedaan hasil belajar kimia yang signifikan pada materi koloid antara siswa yang diajarkan dengan model pembelajaran berbasis proyek dengan model pembelajaran berbasis masalah siswa kelas XI IPA MAN 2 Mataram Tahun Ajaran 2013/2014.Tujuannya adalah untuk mengetahui model pembelajaran mana yang lebih efektif dalam meningkatkan hasil belajar kimia pada materi koloid di kelas XI IPA MAN 2 Mataram tahun ajaran 2013/2014.

\section{HASIL DAN PEMBAHASAN}

Hasil post-test pada kelas XI IPA U1 (penerapan pembelajaran berbasis proyek) diperoleh nilai rata-rata kelas sebesar 67 dan ketuntasan klasikal sebesar 7,69\%, sedangkan pada kelas XI IPA U2 (penerapan pembelajaran berbasis masalah) diperoleh nilai rata-rata sebesar 70 dan ketuntasan klasikalnya sebesar 28,57\% dengan kriteria ketuntasan minimal (KKM) sebesar 80. Nilai rata-rata kedua kelas dapat dilihat pada gambar 1 dimana nilai rata-rata kelas penerapan model pembelajaran berbasis masalah (PBL) lebih tinggi daripada kelas penerapan model pembelajaran berbasis proyek (PjBL).Hal ini disebabkan siswa di kelas penerapan model pembelajaran berbasis masalah lebih banyak mendapatkan bimbingan guru ketika praktikum untuk memecahkan masalah, sedangkan siswa di kelas penerapan model pembelajaran berbasis proyek tidak mendapatkan bimbingan guru ketika membuat produk proyeknya di luar jam belajar. 


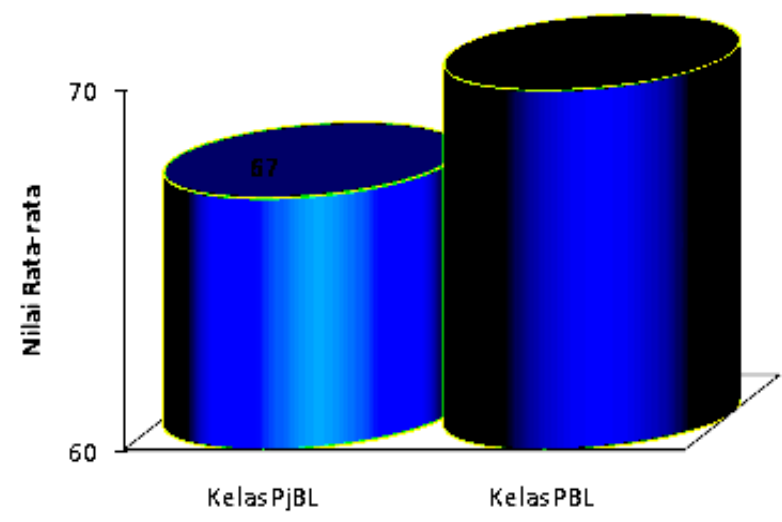

Gambar 1 Nilai Rata-Rata Hasil Posttest

Hasil uji-t dua pihak diperoleh nilai $-\mathrm{t}_{\text {tabel }} \leq \mathrm{t}$ hitung $<+t_{\text {tabel }}$, yakni $-1,708 \leq 0,722<1,708$. Dengan demikian, maka hipotesis nol $\left(\mathrm{H}_{\mathrm{o}}\right)$ diterima yaitu tidak terdapat perbedaan yang signifikan pada hasil belajar kimia materi Koloid siswa yang diajar dengan menggunakan model pembelajaran berbasis proyek dengan model pembelajaran berbasis masalah. Diterimanya $\mathrm{H}_{\mathrm{o}}$ disebabkan karena aktivitas siswa pada kedua model yang diterapkan kurang lebih sama dan kedua model pembelajaran ini pada dasarnya memiliki banyak kesamaan, yaitu sama-sama menekankan pada diskusi kelompok untuk menemukan solusi dari permasalahan yang ada, serta menuntut siswa untuk belajar mandiri dalam kelompoknya untuk menjawab pertanyaan-pertanyaan, sehingga sangat memungkinkan jika hasil belajar yang diperoleh juga relatif sama.Selain itu, hal tersebut dipengaruhi beberapa faktor, diantaranya ketidaksiapan belajar dan interaksi antar siswa.

Ketidaksiapan belajar siswa di kelas pembelajaran berbasis proyek dan kelas pembelajaran berbasis masalah sudah tampak dari pertemuan pertama, terbukti hanya ada satu macam buku paket kimia sebagai referensi dalam belajar. Hal ini sesuai dengan pendapat Slameto [7], bahwa siswa yang telah memiliki kesiapan dalam belajar maka hasil belajarnya akan lebih baik dan begitupula sebaliknya.

Interakasi yang baik dapat terlihat pada masing-masing siswa di kelas pembelajaran berbasis proyek dan kelas pembelajaran berbasis masalah. Hal ini ditunjukkan pada saat siswa melakukan diskusi kelompok maupun diskusi kelas, siswa terlihat sangat aktif menjawab dan mengajukan pertanyaan, mempertahankan pendapat, berusaha memberikan hasil akhir/produk yang lebih baik dari siswa atau kelompok lain serta berusaha untuk menyelesaikan praktikum sesuai dengan tujuan yang ingin dicapai. Interaksi seperti ini dapat mempengaruhi hasil belajar siswa.Pernyataan tersebut sesuai dengan pendapat Slameto [8] yang menyatakan bahwa interaksi yang baik antar siswa dapat memberikan pengaruh yang postif terhadap hasil belajar siswa. Hal tersebut juga didukung oleh Noordin [4] bahwa dalam proses pelaksanaannya, model pembelajaran berbasis proyek dan pembelajaran berbasis masalah sangat memerlukan peran aktif siswa. Adapun jumlah siswa yang aktif di kelas penerapan model pembelajaran berbasis proyek dan pembelajaran berbasis masalah hampir sama, seperti yang terlihat pada gambar 2 di bawah ini.

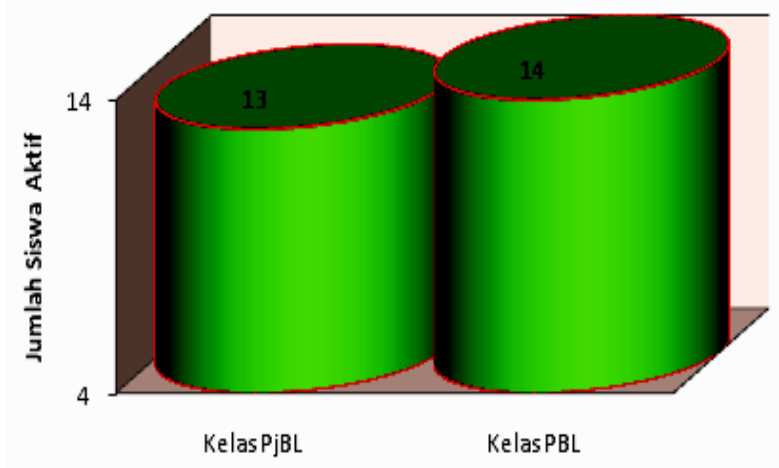

Gambar 2 Jumlah Siswa yang Aktif selama Proses Pembelajaran di Kelas

Berdasarkan gambar 2 terlihat bahwa siswa yang aktif selama proses pembelajaran di kelas PjBL dan PBL hampir sama, yaitu masing-masing berjumlah 13 dan 14 orang siswa. Hal ini disebabkan kedua model pembelajaran tersebut sama-sama memerlukan peran aktif siswa agar bisa terlaksana dengan baik.

\section{Ketuntasan Klasikal}

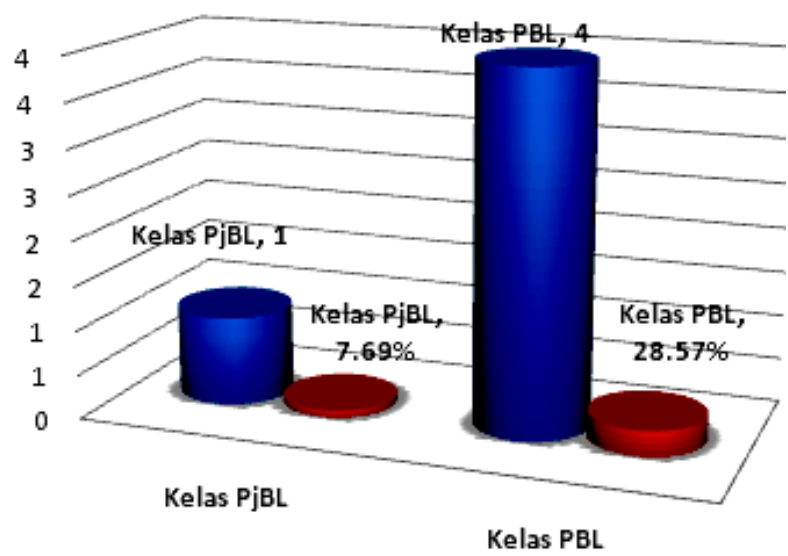

Gambar 3 Persentase Ketuntasan Klasikal

Keterangan :

: Jumlah siswa yang tuntas

: Persentase ketuntasan klasikal

Ketuntasan klasikal yang dicapai peneliti baik pada penerapan model pembelajaran berbasis proyek maupun pada penerapan model pembelajaran berbasis masalah belum mencapai ketuntasan standar yaitu $75 \%$. Persentase ketuntasan klasikal kedua kelas eksperimen dapat dilihat pada gambar 3.

Berdasarkan gambar 3 terlihat bahwa ketuntasan klasikal di kelas penerapan model PBL lebih tinggi daripada di kelas penerapan model $\mathrm{PjBL}$, walaupun ketuntasan klasikal kedua kelas masih tergolong rendah. Hal ini disebabkan oleh beberapa kendala pada tahap inti pembelajaran. Kendala-kendala 
tersebut diantaranya adalah waktu yang tidak cukup, kondisi kelas yang sulit dikontrol ketika melakukan praktikum dan presentasi serta hanya sebagian siswa yang aktif selama proses pembelajaran.

Kendala pertama pada penerapan pembelajaran berbasis proyekadalah waktu yang tidak cukup untuk melaksanakan presentasi semua kelompok di kelas, padahal presentasi ini merupakan kesempatan bagi siswa untuk menyampaikan rancangan produk dari tugas proyek yang sudah disusun. Rancangan produk tersebut harus dikoreksi oleh guru, sehingga produk yang dihasilkan sesuai dengan yang ditugaskan pada LKP. Kedua, kondisi kelas sulit dikontrol. Pada saat proses pembelajaran, banyak siswa yang sibuk dengan tugas proyek kelompoknya sendiri dan kurang memperhatikan ketika kelompok lain melakukan presentasi yang mengakibatkan tidak semua siswa aktif selama presentasi dilaksanakan. Ketiga, adanya kelompok yang hanya mengandalkan temannya yang lebih pintar untuk menjawab pertanyaan-pertanyaan tugas proyek yang terdapat pada LKP, sehingga diperoleh hanya 13 orang dari 29 siswa yang aktif selama proses pembelajaran berbasis proyek. Keempat, waktu yang sedikit untuk menjawab soal post test karena pertemuan terakhir untuk kelas pembelajaran berbasis proyek digabung dengan waktu post test.Hal ini disebabkan pertemuan tersebut adalah hari terakhir aktif belajar di sekolah, sehingga siswa terburu-buru dalam menjawab soal post test sebanyak 30 soal dalam waktu 45 menit.

Ketuntasan klasikal pada penerapan model pembelajaran berbasis masalahjuga tergolong rendah. Penyebab pertama, kendala waktu sangat dirasakan ketika presentasi hasil praktikum karena tidak semua kelompok bisa mempresentasikan dan menanggapi hasil praktikum kelompok lain, sehingga hanya sedikit waktu bagi guru untuk memberikan penguatan terkait materi yang sudah dipraktikkan. Hal ini disebabkan lebih banyak waktu yang dihabiskan untuk melakukan praktikum, akibatnya tidak semua konsep materi bisa dipahami oleh siswa. Kedua, kondisi kelas sulit dikontrol. Pada saat proses pembelajaran, banyak siswa yang sibuk dengan tugas praktikum kelompoknya sendiri dan kurang memperhatikan ketika kelompok lain melakukan presentasi yang mengakibatkan tidak semua siswa aktif selama presentasi dilaksanakan. Ketiga, adanya kelompok yang hanya mengandalkan temannya yang lebih pintar untuk menjawab pertanyaan-pertanyaan tugas praktikum yang terdapat pada LKS, sehingga diperoleh hanya 14 orang dari 28 siswa yang aktif selama proses pembelajaran berbasis masalah. Keempat, peneliti kesulitan dalam mengontrol setiap kelompok. Banyak kelompok yang ingin berkonsultasi ataupun bertanya sebelum guru selesai menjelaskan pertanyaan dari kelompok yang lain, sehingga suasana kelas menjadi kurang kondusif.

Selain faktor-faktor internal, ada juga faktor eksternal yang berpengaruh dalam belajar seperti keadaan lingkungan belajar, guru dan cara mengajarnya, serta alat-alat yang dipergunakan dalam belajar mengajar [8]. Kedekatan antara guru (peneliti) dengan siswa masih kurang, dimana guru mengajar disana hanya pada saat penelitian, sehingga pendalaman karakter untuk masing-masing siswa masih belum cukup untuk mengenal satu sama lain yang berpengaruh terhadap pengelolaan kelas. Referensi dalam belajar juga masih sangat minim. Hanya sebagian kecil siswa yang memiliki buku paket kimia, walaupun guru membagikan LKP ataupun LKS namun hanya dibagikan masing-masing 1 LKP ataupun LKS untuk 1 kelompok, sehingga siswa kurang leluasa untuk mempelajarinya.

Berdasarkan pemaparan di atas, dengan melihat hasil analisis data dapat disimpulkan bahwa model pembelajaran berbasis proyektidak berbeda secara signifikan dengan model pembelajaran berbais masalah. Namun, secara klasikal model pembelajaran berbasis masalah memberikan hasil yang lebih baik yaitu 28,57\% dibandingkan ketuntasan klasikal pada model pembelajaran berbasis proyek yaitu 7,69 \% pada materi Koloid. Ketuntasan klasikal yang lebih tinggi di kelas pembelajaran berbasis masalah disebabkan oleh karakteristik materi koloid sesuai dengan karakteristik model pembelajaran berbasis masalah yang lebih menekankan pada kemampuan berpikir siswa (materi berupa fakta dan konsep), sedangkan model pembelajaran berbasis proyek lebih cocok pada materi yang mengarah pada pembuatan produk akhir dan seluruh proses produksi (Noordin, 2011). Oleh karena itu, model pembelajaran berbasis masalah lebih efektif diterapkan pada materi Koloid, khususnya pada kelas XI IPA Unggulan di MAN 2 Mataram yang kegiatan pembelajarannya mengacu pada KTSP yang didukung oleh keaktifan siswa dan fasilitas pembelajaran yang memadai.

\section{KESIMPULAN}

Berdasarkan hasil penelitian dan pembahasan, maka dapat disimpulkan bahwa tidak terdapat perbedaan hasil belajar kimia yang signifikan pada materi koloid antara siswa yang diajarkan dengan model pembelajaran berbasis proyek dengan model pembelajaran berbasis masalah siswa kelas XI IPA MAN 2 Mataram Tahun Ajaran 2013/2014. Namun berdasarkan ketuntasan klasikal, model pembelajaran berbasis masalah lebih efektif diterapkan pada materi Koloid yang kegiatan pembelajarannya mengacu pada KTSP berdasarkan persentase ketuntasan klasikal yang didukung oleh keaktifan siswa dan fasilitas pembelajaran yang memadai.

\section{DAFTAR PUSTAKA}

[1] Manasikana, Oktaffi Arinna, Ashadi, dan Haryono. 2012. Pembelajaran IPA Melalui Metode Inkuiri Terbimbing dan Proyek Ditinjau dari Kreativitas dan Kemampuan Menggunakan Alat Laboratorium. Jurnal Inkuiri, Volume 01, Nomor 01, Tahun 2012: Halaman 24-25. 
[2] Departemen Pendidikan Nasional. 2008. Kurikulum Tingkat Satuan Pendidikan. Direktorat Tenaga Kependidikan.

[3] Siwa, I Bagus, dan I Wayan Muderawan, IN. Tika. 2013. Pengaruh Pembelajaran Berbasis Proyek dalam Pembelajaran Kimia terhadap Keterampilan ProsesSains Ditinjau dari Gaya Kognitif Siswa.e-Journal Program Pascasarjana Universitas Pendidikan GaneshaProgram Studi IPA, Volume 03, Tahun 2013: Halaman 2.

[4] Noordin, Muhammad Khair, Ahmad Nabil Natsir, Dayana Farzeeha Ali, Mohd Safarin Nordin. 2011. Problem-Based Learning (PBL) and Project-Based Learning (PjBL) in Engineering Education: a Comparison. Disajikan dalam the IETEC'11 Conference, Kuala Lumpur, Malaysia.

[5] Ayşe, Oğuz Ünver, Sertaç Arabacioğlu. 2011. Overviews on Inquiry Based and Problem Based Learning Methods. WAJES, Tahun 2011: Halaman 306.

[6] Sugiyono. 2011. Metode Penelitian Kuantitatif Kualitatif dan $R \&$ D. Bandung : Alfabeta.

[7] Slameto. 2010. Belajar dan Faktor-Faktor yang Mempengaruhinya. Jakarta: Rineka Cipta.

[8] Djamarah, B.S., 2008. Psikologi Belajar (Edisi 2). Jakarta: Rineka Cipta. 